of a 12-year-old tree. Amer. J. Bet. 75:767777.

Momot, T.S. and A.M. Smirnov. 1978. Organogenesis from various organs of the $\mathrm{Si}$ berian and Dahur larch (Larix sibirica Maxim. and $L$. dahurica Turcz.) and yellow pine ( $P i$ nus ponderosa Dougl.) cultured in vitro. Izv. Acad. Nauk. SSSR. Ser. B. 5(6):758-761.
(Engl. trans.)

Owens, J.N. and M. Molder. 1979. Bud development in Larix occidentals. 1. Growth and development of vegetative long shoot and vegetative short shoot buds. Can. J. Bet. 57(7):687-700

Reilly, K. and J. Washer. 1977. Vegetative propagation of radiata pine by tissue culture:
Plantlet formation from embryonic tissue. New Zealand J. For. Sci. 7:199-206.

Thompson, D.G. and J.B. Zaerr. 1981. Induction of adventitious buds on cultured shoot tips of Douglas-fir (Pseudotsuga menziesii (Mirb.)Franco). Colloque Intl. sur la Culture "in vitro" des essences Forestières. Fountainbleau, France.

\section{Use of Dyes to Facilitate Measurement of New Root Growth of Apple}

\author{
Michael A. Arnold ${ }^{1}$ and Eric Young ${ }^{2}$ \\ Department of Horticultural Science, North Carolina State University, \\ Raleigh, NC 27695-7609 \\ Additional index words. Malus domestics, safranin-O, methylene blue, neutral red, \\ crystal violet, alizarin red $\mathrm{S}$, root regeneration potential, root regeneration capacity
}

\begin{abstract}
The root systems of dormant l-year-old apple (Malus domestics Borkh. 'Starkrimson') grafted on seedling rootstock were dipped for 15 seconds in one of six dye treatments or a water control. Trees were destructively harvested at 15,30 , and 90 days after treatment to monitor new root and shoot growth and effectiveness of dyes for distinguishing between regenerated roots and those present at planting. Neutral red and methylene blue allowed effective separation of new and old roots through 90 days after treatment, and had few adverse effects on root or shoot growth, with a water control being the standard. Crystal violet and safranin-O allowed effective separation between regenerated and previously existing roots, but these dyes adversely affected new root and shoot growth. Alizarin red $S$ and Hantover meat branding ink were ineffective for distinguishing between regenerated and previously existing roots by 15 days after treatment.
\end{abstract}

In studies involving determination of root regeneration potential (RRP), or root regeneration capacity (RRC), it is important to distinguish between regenerated and previously existing roots. RRP or RRC consists of two components, elongation "of existing roots, and/or initiation of new adventitious roots (Sutton and Tinus, 1983). RRP or RRC is usually estimated by measuring the white root tips (number, length, weight) appearing under specified environmental conditions over a certain period (Sutton and Tinus, 1983). Such measurements may bean unambiguous means of estimating root regeneration over short periods. However, over longer periods, regenerated roots may undergo metacutization and root browning, therefore becoming

Received for publication 28 Nov. 1988. Paper no. 11924 of the Journal Series of the North Carolina Agricultural Research Service, Raleigh, NC 27695 7601. This study will be included as part of a dissertation to be written in partial fulfillment of the requirements for the $\mathrm{PhD}$ degree by M.A.A. The use of trade names in this publication does not imply endorsement by the NCARS of the products named, nor criticism of similar ones not mentioned. The cost of publishing this paper was defrayed in part by the payment of page charges. Under postal regulations, this paper therefore must be hereby marked advertisement solely to indicate this fact.

Graduate Research Assistant.

'Professor. indistinguishable from older existing roots. In apple, this change may occur within a week under certain environmental conditions (Rogers, 1939).

Schumacher et al. (1983) found that neutral red dye at several concentrations was an effective and non-toxic root dye for Phaseolus vulgaris L. and Glycine max L. However, their studies were brief (6 to 12 days) and involved only recently germinated herbaceous seedlings. Carman (1982) developed a nondestructive staining technique to measure new root growth over time using individual soil drenches with red, blue, and yellow chlorotiazinyl dyes. However, this technique is limited to container studies using porous media and mild staining conditions. The effectiveness of Carman's technique for studying woody plant root growth is unknown, as the study was also limited to recently germinated herbaceous seedlings of Sorghum bicolor (L.) Moench. Kaufmann (1968) tested neutral red, orange H, India black ink, safranin-O, and methyl violet as root dyes on Pinus echinata Mill. Only safranin-O and methyl violet were considered effective for separating old from new roots. While Kaufmann observed no apparent toxicity problems, he cautioned that further evaluation was needed before making largescale use of this technique. Additionally, no data were presented on growth effects of the dyes.
Objectives of this study were to: 1) determine if unsuberized roots (Sutton and Tinus, 1983) encompassed all the newly regenerated roots within the first 15 to 30 days after planting; 2) evaluate the effectiveness of selected dyes for distinguishing between newly regenerated roots and those present at planting; and 3) determine if the dyes had any effects on plant growth and development.

Fully chilled, dormant, 1-year-old 'Starkrimson' on seedling rootstock were rootpruned to $20 \mathrm{~cm}$ below the root collar and dipped for $15 \mathrm{sec}$ in one of six dye treatments or a water control. Dye treatments included safranin-O (basic red 2), methylene blue (basic blue 9), neutral red (toluylene red), crystal violet (basic violet 3, gentian violet, methyl violet), alizarin red $\mathrm{S}$ (all obtained from Sigma, St. Louis) and Hantover meat branding ink (Hantover, Kansas City, Me. ) dissolved in water at $1 \%(\mathrm{w} / \mathrm{v})$ [as used by Kaufmann, (1968)]. Safranin-O and crystal violet (methyl violet) were chosen based on Kaufmann's (1968) reported success and neutral red based on Schumacher et al. (1983). Methylene blue and alizarin red S were included because they can stain cutinized cell walls and they have high volubility in water, respectively (Johansen, 1940). Hantover meat branding ink was selected because it was inexpensive and, based on its use as a meat dye, nontoxic to humans.

Root systems were placed between moist paper towels for $10 \mathrm{~min}$ to allow excess dye to drain from the root system. On 21 Apr. 1988, 15 seedlings of each dye treatment and the control were potted in Turface (calcined clay) medium in 3.5-liter containers and placed in a completely randomized design on a greenhouse bench. Plants were watered as needed and fertilized weekly with $125 \mathrm{ppm}$ $\mathrm{N}$ from 20N-8.7P-16.6K Peters water-soluble fertilizer (W.R. Grace, Fogekville, Pa.). Temperatures were set at 24/18C day/night with natural photoperiods.

Five seedlings of each treatment and control were destructively harvested after 15 , 30, and 90 days. Shoot characteristics measured included new and old total shoot lengths, new and old shoot fresh weights, new shoot dry weights, total number of vegetative buds, number of buds showing any green (budbreak), and number of buds elongating ( $\geq 3$ $\mathrm{mm})$. Measured root characteristics were old root fresh weight, new root fresh and dry weights, number and total length of roots $\geq 0.6 \mathrm{~mm}$ in diameter (large roots, days 15 and 30 only), number of roots $<0.6 \mathrm{~mm}$ in diameter (small roots, days 15 and 30 only). 
Table 1. Root and shoot growth at 15 days after dye treatment of the root system of dormant 'Starkrimson' on seedling rootstock in year $1 .{ }^{2}$

\begin{tabular}{|c|c|c|c|c|c|c|c|c|c|c|c|c|}
\hline \multirow[b]{2}{*}{ Dye } & \multicolumn{3}{|c|}{ New shoot } & \multirow[b]{2}{*}{$\begin{array}{c}\text { Budbreak } \\
(\%)\end{array}$} & \multirow{2}{*}{$\begin{array}{c}\text { New root/ } \\
\text { shoot } \\
\text { fresh wt } \\
\left(g \cdot g^{-1}\right)\end{array}$} & \multirow{2}{*}{$\begin{array}{c}\text { New root/ } \\
\text { shoot } \\
\text { dry wt } \\
\left(\mathrm{g} \cdot \mathrm{g}^{-1}\right)\end{array}$} & \multicolumn{2}{|c|}{ No. roots ${ }^{y}$} & \multicolumn{3}{|c|}{ New large root } & \multirow{2}{*}{$\begin{array}{c}\text { Root } \\
\text { surface } \\
\text { area } \\
\left(\mathrm{mm}^{2}\right)\end{array}$} \\
\hline & $\begin{array}{l}\text { Length } \\
(\mathrm{mm})\end{array}$ & $\begin{array}{c}\text { Fresh wt } \\
\text { (g) }\end{array}$ & $\begin{array}{c}\text { Dry wt } \\
(\mathrm{g})\end{array}$ & & & & $\frac{\text { No. } 1}{\text { Small }}$ & $\frac{\text { ots }}{\text { Large }}$ & $\begin{array}{l}\text { Length } \\
\text { (mm) }\end{array}$ & $\begin{array}{c}\text { Fresh wt } \\
(\mathrm{g})\end{array}$ & $\begin{array}{c}\text { Dry wt } \\
(\mathrm{g})\end{array}$ & \\
\hline None & 602 & 3.51 & 0.87 & 38 & 0.08 & 0.26 & 68 & 26 & 493 & 0.37 & 0.02 & 673 \\
\hline $\begin{array}{l}\text { Safranin-O } \\
\text { Methylene }\end{array}$ & 670 & 3.64 & 0.83 & 47 & $0.04^{*}$ & 0.19 & 73 & 25 & 464 & 0.20 & 0.02 & 612 \\
\hline $\begin{array}{l}\text { blue } \\
\text { Neutral }\end{array}$ & 469 & 2.52 & 0.69 & 37 & 0.11 & 0.37 & 66 & 28 & 506 & 0.32 & 0.02 & 771 \\
\hline $\begin{array}{l}\text { red } \\
\text { Crystal }\end{array}$ & 516 & 3.04 & 0.70 & 38 & 0.07 & 0.16 & 133 & 24 & 471 & 0.33 & 0.02 & 733 \\
\hline violet & 428 & $2.14^{*}$ & $0.58^{*}$ & 38 & $0.03^{* *}$ & $0.06^{*}$ & $23^{*}$ & 9 & $161^{*}$ & $0.08^{* * *}$ & $0.00^{* * *}$ & $195^{*}$ \\
\hline
\end{tabular}

${ }^{2}$ Values are means of five observations.

'Diameter; small, <0.6 mm; large, $\geq 0.6 \mathrm{~mm}$

*******Significantly different from the control at $P \leq 0.20,0.10$, or 0.05 , respectively.

A random, sample of 10 diameters of large dissecting microscope for calculations of large root surface area. New root : new shoot ratios, percent budbreak (number of buds broken/total number of buds), and large root surface area $\left[3.14 \mathrm{r}\left(r^{2}+\right.\right.$ new root length $\left.^{2}\right)^{1 / 2}$; days 15 and 30 only] were calculated. Means were separated using a leastsquares means procedure (SAS Institute, 1985) because one plant at day 90 was missing.

Following each harvest, cross-sections of the primary root were made at the pruned roots for each plant was measured under a

surface, $1 \mathrm{~cm}$ behind the pruned surface, the midpoint of the root, and at the graft union. The bark was stripped from the remaining primary root sections to visually determine the extent of dye uptake and staining.

To achieve greater precision in estimating the effects of the two most promising dyes on initial root and shoot growth, the growth portions of the experiment were repeated (5 May 1989) for the control, methylene blue, and neutral red treatments using 15 plants per treatment. The plants were placed in a randomized complete-block design in the greenhouse with growth conditions as de-

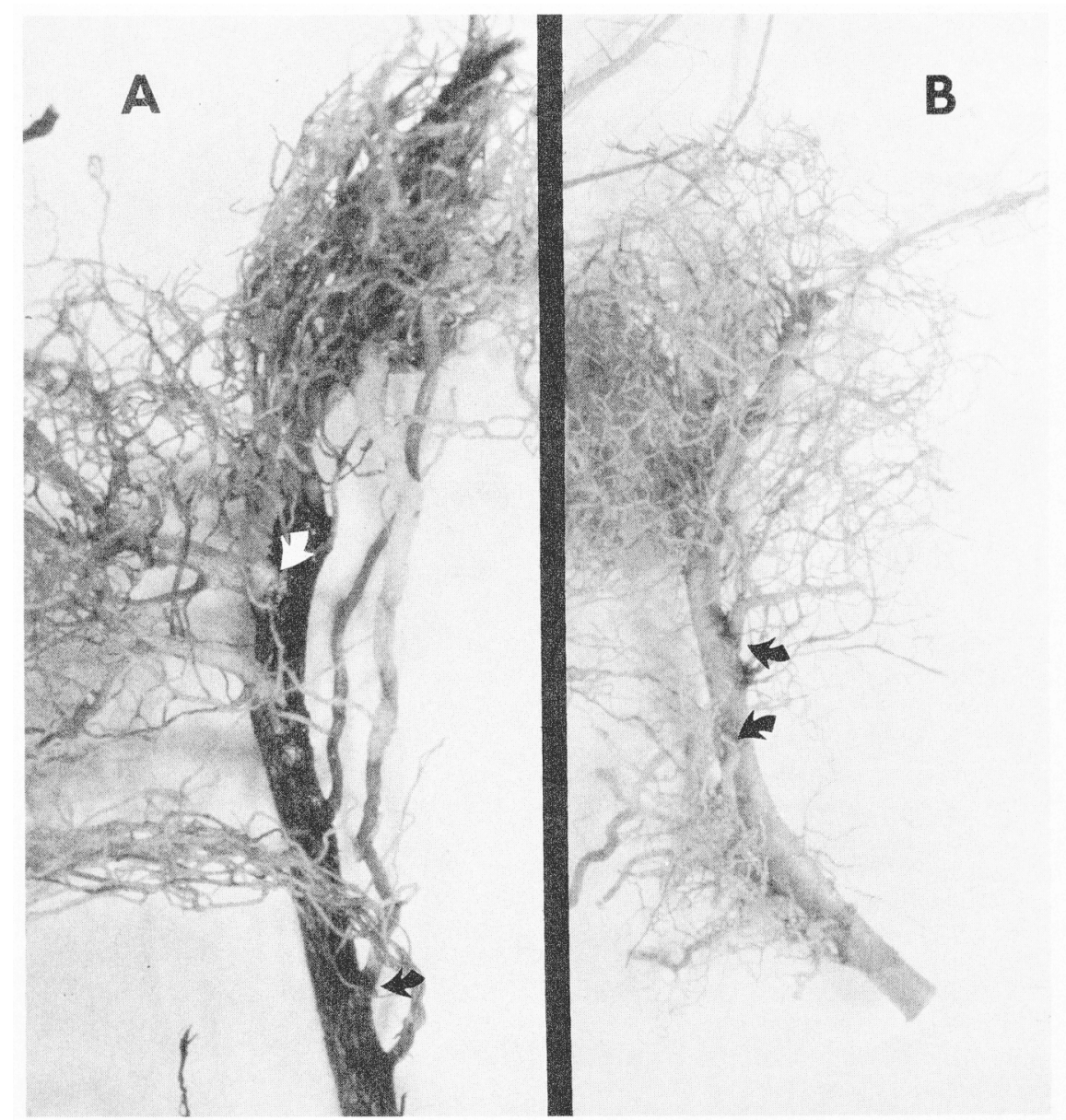

Fig. 1. Regenerated apple roots from methylene blue-treated roots (A) and untreated control roots (B) 90 days after treatment. Arrows indicate transition between regenerated roots and those present at treatment. scribed previously. After 15 days, growth characteristics were measured and analyzed as described previously.

Unsuberized, white, and-light brown roots and roots originating from pruned surfaces were assumed to be newly regenerated tissue. Using this premise, new roots on the controls were distinguished easily from old roots on the basis of degree of suberization, browning, and position at 15 and 30 days after planting. Use of the above criteria to distinguish new root growth for controls during the first 30 days after treatment showed no under- or over-estimation of new root tissue compared to the less-ambiguous dye treatment criteria (Tables 1-3). At 90 days after treatment, although the above criteria did not significantly underestimate the amount of new root tissue in controls (Table 4), the decision as to which portions were actually new root tissue or root tissue existing at planting was much more difficult. On plants dyed with safranin-O, methylene blue, neutral red, and crystal violet, stained roots were assumed to be old roots and those that were unstained assumed to be new tissue. These four dyes appeared to be immobile on exterior root surfaces since there were sharp and clear separations from dyed surfaces on old roots to undyed surfaces of new roots through 90 days after treatment (Fig. 1). These dyes were, therefore, effective in distinguishing newly regenerated from previously existing roots. Alizarin red S and Hantover meat branding ink were ineffective by 15 days after treatment due to color fading or dilution and were excluded from further analysis.

Cross-sections of the primary roots of control seedlings and those treated with methylene blue, safranin-O, crystal violet, and neutral red revealed that dyes predominately stained cortical cells, confirming the findings of Schumacher et al. (1983) with neutral red. However, bark stripping and root cross-sections showed that dyes were also taken up in the xylem, usually for short distances, from root-pruned surfaces and areas in which the bark was injured. In no cases were dyes translocated $>10 \mathrm{~cm}$.

Because one of the objectives of this study was to eliminate any dye that may influence plant growth and development, high $\alpha$ levels of 0.20 and 0.10 were included in the analy- 
Table 2. Root and shoot growth at 30 days after dye treatment of the root system of dormant 'Starkrimson' on seedling rootstock in year $1 .{ }^{2}$

\begin{tabular}{|c|c|c|c|c|c|c|c|c|c|c|c|c|}
\hline \multirow[b]{2}{*}{ Dye } & \multicolumn{3}{|c|}{ New shoot } & \multirow[b]{2}{*}{$\begin{array}{c}\text { Budbreak } \\
(\%)\end{array}$} & \multirow{2}{*}{$\begin{array}{c}\text { New root/ } \\
\text { shoot } \\
\text { fresh wt } \\
\left(\mathrm{g} \cdot \mathrm{g}^{-1}\right)\end{array}$} & \multirow{2}{*}{$\begin{array}{l}\text { New root/ } \\
\text { shoot } \\
\text { dry wt } \\
\left(\mathrm{g} \cdot \mathrm{g}^{-1}\right)\end{array}$} & & & \multicolumn{3}{|c|}{ New large root } & \multirow{2}{*}{$\begin{array}{c}\text { Root } \\
\text { surface } \\
\text { area } \\
\left(\mathrm{mm}^{2}\right)\end{array}$} \\
\hline & $\begin{array}{l}\text { Length } \\
\text { (mm) }\end{array}$ & $\begin{array}{c}\text { Fresh wt } \\
(\mathrm{g})\end{array}$ & $\begin{array}{c}\text { Dry wt } \\
(\mathrm{g})\end{array}$ & & & & $\begin{array}{c}\text { No. } \mathrm{r} \\
\text { Small }\end{array}$ & $\frac{\mathrm{oots}^{\mathrm{y}}}{\text { Large }}$ & $\begin{array}{l}\text { Length } \\
(\mathrm{mm})\end{array}$ & $\begin{array}{c}\text { Fresh wt } \\
(\mathrm{g})\end{array}$ & $\begin{array}{c}\text { Dry wt } \\
(\mathrm{g})\end{array}$ & \\
\hline None & 1437 & 12.10 & 2.93 & 42 & 0.10 & 0.53 & 576 & 53 & 1367 & 1.41 & 0.16 & 2399 \\
\hline $\begin{array}{l}\text { Safranin-O } \\
\text { Methylene }\end{array}$ & 1082 & 9.56 & 2.34 & 37 & 0.09 & 0.27 & 364 & 29 & 1041 & 0.97 & 0.21 & 1973 \\
\hline $\begin{array}{l}\text { blue } \\
\text { Neutral }\end{array}$ & 1169 & 10.61 & 2.63 & $33^{*}$ & 0.19 & 0.53 & 909 & 54 & 2177 & 2.47 & 0.17 & $4509^{*}$ \\
\hline $\begin{array}{l}\text { red } \\
\text { Crystal }\end{array}$ & $780^{*}$ & 8.75 & 2.11 & $30 * *$ & 0.18 & 0.71 & 654 & 32 & 1157 & 1.00 & 0.05 & 1976 \\
\hline violet & 1557 & 13.42 & 3.44 & 44 & 0.19 & 0.48 & $1220^{*}$ & 56 & $2521 *$ & $3.01 *$ & $0.29 * *$ & 4084 \\
\hline
\end{tabular}

${ }^{2}$ Values are means of five observations.

'Diameter: small, $<0.6 \mathrm{~mm}$; large, $\geq 0: 6 \mathrm{~mm}$.

$*, * *$ Significantly different from control at $P \leq 0.20$ or 0.10 , respectively.

Table 3. Root and shoot growth at 15 days after dye treatment of the root system of dormant 'Starkrimson' on seedling rootstock in year 2 . $^{2}$

\begin{tabular}{|c|c|c|c|c|c|c|c|c|c|c|c|c|}
\hline \multirow[b]{2}{*}{ Dye } & \multicolumn{3}{|c|}{ New shoot } & \multicolumn{5}{|c|}{$\begin{array}{c}\text { New root/ New root/ } \\
\text { shoot }\end{array}$} & \multicolumn{3}{|c|}{ New large root } & \multirow{2}{*}{$\begin{array}{c}\text { Root } \\
\text { surface } \\
\text { area } \\
\left(\mathrm{mm}^{2}\right)\end{array}$} \\
\hline & $\begin{array}{l}\text { Length } \\
(\mathrm{mm})\end{array}$ & $\begin{array}{c}\text { Fresh wt } \\
(\mathrm{g})\end{array}$ & $\begin{array}{c}\text { Dry wt } \\
(\mathrm{g})\end{array}$ & $\begin{array}{c}\text { Budbreak } \\
(\%)\end{array}$ & $\begin{array}{c}\text { fresh wt } \\
\left(\mathrm{g} \cdot \mathrm{g}^{-1}\right)\end{array}$ & $\begin{array}{l}\text { dry wt } \\
\left(\mathrm{g} \cdot \mathrm{g}^{-1}\right)\end{array}$ & No. roots ${ }^{y}$ & $\frac{\text { oots }^{y}}{\text { Large }}$ & $\begin{array}{l}\text { Length } \\
(\mathrm{mm})\end{array}$ & $\begin{array}{c}\text { Fresh wt } \\
(\mathrm{g})\end{array}$ & $\begin{array}{c}\text { Dry wt } \\
(\mathrm{g})\end{array}$ & \\
\hline $\begin{array}{l}\text { None } \\
\text { Methylene }\end{array}$ & 1401 & 9.98 & 2.56 & 73 & 0.026 & 0.008 & 215 & 33 & 852 & 0.40 & 0.03 & 924 \\
\hline $\begin{array}{l}\text { Menylene } \\
\text { blue } \\
\text { Neutral }\end{array}$ & 1460 & $11.75^{*}$ & $2.99 *$ & $78^{*}$ & 0.022 & 0.009 & 318 & 34 & 696 & 0.32 & 0.03 & 933 \\
\hline red & 1262 & 9.21 & 2.42 & $78 *$ & 0.019 & 0.008 & 185 & 23 & 549 & 0.27 & 0.03 & 790 \\
\hline
\end{tabular}

${ }^{2}$ Values are means of 15 observations.

'Diameter: small, < $0.6 \mathrm{~mm}$; large, $\geq 0.6 \mathrm{~mm}$.

*Significantly different from the control at $P \leq 0.20$.

Table 4. Root and shoot growth at 90 days after dye treatment of the root system of dormant 'Starkrimson' on seedling rootstock in year 1.'

\begin{tabular}{|c|c|c|c|c|c|c|c|c|}
\hline \multirow[b]{2}{*}{ Dye } & \multicolumn{3}{|c|}{ New shoot } & \multirow{2}{*}{$\begin{array}{c}\text { Budbreak } \\
(\%)\end{array}$} & \multirow{2}{*}{$\begin{array}{c}\text { New root/ } \\
\text { shoot } \\
\text { fresh wt } \\
\left(\mathrm{g} \cdot \mathrm{g}^{-1}\right)\end{array}$} & \multirow{2}{*}{$\begin{array}{c}\text { New root/ } \\
\text { shoot } \\
\text { dry wt } \\
\left(\mathrm{g} \cdot \mathrm{g}^{-1}\right)\end{array}$} & \multicolumn{2}{|c|}{$\frac{\text { New large root }}{\text { Fresh wt Dry wt }}$} \\
\hline & $(\mathrm{mm})$ & (g) & $(\mathrm{g})$ & & & & (g) & $(\mathrm{g})$ \\
\hline None & $2523^{y}$ & 59.37 & 21.22 & 36 & 1.07 & 1.00 & 64.62 & 9.64 \\
\hline $\begin{array}{l}\text { Safranin-O } \\
\text { Methylene }\end{array}$ & 2208 & 54.48 & 18.66 & 31 & $0.82 *$ & $0.86^{*}$ & $48.61 *$ & 7.13 \\
\hline $\begin{array}{l}\text { blue } \\
\text { Neutral }\end{array}$ & 2507 & 61.02 & 21.14 & 35 & 1.11 & 0.91 & 70.05 & 10.57 \\
\hline $\begin{array}{l}\text { red } \\
\text { Crystal }\end{array}$ & 2947 & 65.09 & 22.66 & 43 & 1.05 & 0.96 & 69.98 & 10.79 \\
\hline violet & 2207 & 52.46 & 17.18 & 32 & $0.84 "$ & 0.88 & $48.83^{*}$ & $6.22 *$ \\
\hline
\end{tabular}

${ }^{2}$ Values are means of five observations.

'Diameter: large, $\geq 0.6 \mathrm{~mm}$.

$*$ Significantly different from the control at $P \leq 0.20$.

sis along with 0.05 . This was done to increase the power of the test to detect any possible differences. Unfortunately, this may result in declaring true differences where none exist (type I error). However, in this experiment it is more important to reduce the possibility of failing to detect true differences when they exist (type II. errors) rather than the reverse.

Crystal violet significantly reduced new root and shoot growth at 15 and 90 days after treatment (Tables 1 and 4) and significantly increased several root growth criteria at 30 days (Table 2). It is unclear why these reductions and increases occurred. However, crystal violet stains chromatin, mitochondria, and other plastids, in addition to lignified and cutinized cell wall components (Johansen, 1940), and thus may alter some normal physiological process. Compared to the control and other dye treatments, regen- erated roots on plants treated with crystal violet tended to emerge more in clumps from pruned surfaces.

Safranin-O also significantly reduced some root and shoot growth characteristics at days 15 and 90 compared to controls (Tables 1 and 4). Safranin-O, like crystal violet, stains genetic materials, specifically dividing chromatin, in addition to cutinized, lignified, and suberized cell wall components (Johansen, 1940).

Methylene blue and neutral red, in addition to being effective for distinguishing between newly regenerated roots and those present at treatment, had little or no effect on root or shoot growth through 90 days after treatment (Tables 1-4). Schumacher et al. (1983) successfully used neutral red to repeatedly dye root systems of $G$. max and $P$. vulgaris without adversely affecting growth. This result suggests that successive staining of root systems with methylene blue, neutral red, or other, as yet untested, dyes of different colors may allow the nondestructive determination of root growth over various time intervals without the limitations of Carman's (1982) technique.

We recommend methylene blue and neutral red at $1 \%(\mathrm{w} / \mathrm{v})$ as dyes for use to facilitate distinction between newly regenerated and previously existing root tissue in studies involving gross morphology and root growth of apple. Further study is needed before the use of these dyes in studies involving chemical analysis of the tissue can be recommended. Contrary to Kaufmann's (1968) observations on P. echinata, crystal violet and safranin-O have adverse effects on new root and/or shoot growth in apple and should not be used as root dyes for apple.

\section{Literature Cited}

Carman, J.G. 1982. A non-destructive stain technique for investigating root growth dynamics. J. Applied Ecol. 19:873-879.

Johansen, D.A. 1940. Plant microtechnique. McGraw-Hill, New York.

Kaufmann, M.R. 1968. Water relations of pine seedlings in relation to root and shoot growth. Plant Physiol. 43:281-288.

Rogers, W.S. 1939. Root studies VIII. Apple root growth in relation to rootstock, soil, seasonal and climatic factors. J. Pomol. Hort. Sci. 17:99130 ,

SAS Institute. 1985. SAS user's guide: Statistics, vers. 5 ed. SAS Institute Inc., Cary, N.C.

Schumacher, T. E., A.J.M. Smucker, A. Eshel, and R.B. Curry. 1983. Measurement of shortterm root growth by prestaining with neutral red. Crop Sci. 23:1212-1214.

Sutton, R.F. and R.W. Tinus. 1983. Root and root system terminology. For. Sci. Monogr. 24:137. 